\title{
Changes in trace elements during lactation in a marine top predator, the grey seal
}

\author{
Sarah Habran ${ }^{\mathrm{a}, *}$, Paddy P. Pomeroy ${ }^{\mathrm{b}}$, Cathy Debier ${ }^{\mathrm{c}}$, Krishna Das $^{\mathrm{a}}$ \\ a Laboratory of Oceanology - MARE B6c, University of Liege, B-4000 Liege, Belgium \\ ${ }^{\mathrm{b}}$ NERC Sea Mammal Research Unit, Scottish Oceans Institute, University of St Andrews, St Andrews KY16 8LB, Scotland, UK \\ ${ }^{\mathrm{c}}$ Institut des Sciences de la vie, Université Catholique de Louvain, Croix du Sud 2/L7.05.08, B-1348 Louvain-la-Neuve, Belgium
}

\section{A R T I C L E I N F O}

\section{Article history:}

Received 19 March 2012

Received in revised form 11 August 2012

Accepted 15 August 2012

\section{Keywords:}

Halichoerus grypus

Trace elements

Lactation

Maternal transfer

\begin{abstract}
A B S T R A C T
Lactation in pinnipeds represents the most significant cost to mothers during the reproductive cycle. Dynamics of trace elements and their mobilization associated with energy reserves during such an intense physiological process remains poorly understood in marine mammals. The changes in tissue concentrations of 11 elements ( $\mathrm{Ca}, \mathrm{Cd}, \mathrm{Cr}, \mathrm{Cu}, \mathrm{Fe}, \mathrm{Hg}, \mathrm{Ni}, \mathrm{Pb}, \mathrm{Se}, \mathrm{V}$, and $\mathrm{Zn}$ ) were investigated in a longitudinal study during the lactation period and during the post-weaning fast period. Blood, milk, blubber, and hair samples were collected sequentially from 21 mother-pup pairs of grey seals (Halichoerus grypus) from the Isle of May in Scotland. Maternal transfer through the milk was observed for all trace elements, except for $\mathrm{Cd}$. As an indicator of the placental transfer, levels in pup lanugo (natal coat) revealed also the existence of maternal transfer and accumulation of all assayed trace elements during the foetal development. The placental and mammary barriers against non-essential metal transfer to offspring appear to be absent or weak in grey seals. Examining the contamination levels showed that this grey seal population seems more highly exposed to $\mathrm{Pb}$ than other phocid populations $(2.2 \mathrm{mg} / \mathrm{kg} \mathrm{dw}$ of grey seal hair). In contrast, blood and hair levels reflected a lower Hg exposure in grey seals from the Isle of May than in harbour seals from the southeastern North Sea. This study also showed that trace element concentrations in blood and blubber could change rapidly over the lactation period. Such physiological processes must be considered carefully during biomonitoring of trace elements, and potential impacts that rapid fluctuations in concentrations can exert on seal health should be further investigated.
\end{abstract}

Crown Copyright @ 2012 Published by Elsevier B.V. All rights reserved.

\section{Introduction}

True seals, or phocids, are marine mammals that can accumulate diverse contaminants, such as organochlorines (Debier et al., 2003b, 2006; Vanden Berghe et al., 2010) and trace elements (Das et al., 2003, 2008), at higher levels than those measured in their surrounding environment. Their position as apex predators in the food chain, their occurrence adjacent to heavily populated Western societies, a long life span, and the chemical characteristics of particular groups contribute to this phenomenon. A small increase in environmental trace element concentrations can lead to significant impacts on marine organisms (Bustamante et al., 2003). Marine mammals are thus considered as sentinel species in the marine environment (Bossart, 2006).

\footnotetext{
* Corresponding author. Tel.: +32 4366 4844; fax: +32 43665147.

E-mail addresses: S.Habran@ulg.ac.be, sarah.habran@gmail.com (S. Habran), pp6@st-andrews.ac.uk (P.P. Pomeroy), cathy.debier@uclouvain.be (C. Debier), Krishna.Das@ulg.ac.be (K. Das).
}

Phocids leave the water and come ashore on land or ice for breeding, suckling their young, moulting, and resting. These periods ashore provide a considerable opportunity for sample collection in comparison with other free-ranging marine mammals. In the eastern Atlantic, female grey seals come ashore to pup in the autumn (Fedak and Anderson, 1982). Mothers each give birth to a single white-coated pup, which they suckle for approximately 18 days (Fedak and Anderson, 1982). Lactation represents the most significant cost to mothers during the reproductive cycle of pinnipeds (Yunker et al., 2005). Female grey seals in the UK fast throughout the nursing period and rely entirely on their endogenous fat and protein reserves to maintain their metabolic demands and to produce milk. They secrete a fat-rich milk in which lipid content ranges from $30 \%$ to $60 \%$ (Pomeroy et al., 1996). Lactating females lose an average of $39 \%$ of their postpartum mass during the lactation period, typically efficiency of mass transfer from mothers to pups in grey seals is 45\% (Pomeroy et al., 1999). Pups moult their white natal coat (also called "lanugo") around the time of weaning and then remain on the breeding colony for 1-4 weeks before going to sea (Reilly, 1991). During this post-weaning period, pups also fast and rely on reserves accumulated during lactation. 
The relatively brief but physiologically active lactation period, followed by a period of post-weaning fast for pups, offers a valuable opportunity to investigate changes in levels of contaminants in adult females and their offspring. Indeed, the mobilization of contaminants potentially associated to energy reserves (lipids and proteins) during such an intense physiological process remains an area of considerable interest for marine mammals. Most information on the transfer of pollutants from mother to offspring through the placenta and through the milk concentrates on anthropogenic organic chemicals. Previous studies (Debier et al., 2003a,b; Pomeroy et al., 1996; Vanden Berghe et al., 2010, 2012) showed that suckling newborns could be exposed to high amounts of organic pollutants (PCBs, PBDEs, etc.) during a critical developmental period of their life. In contrast, few studies (Habran et al., 2011; Wagemann et al., 1988) have investigated levels of trace elements in relation to reproduction and maternal transfer of body burdens.

In addition to their natural occurrence, trace elements in marine environment arise from anthropogenic releases associated to increased urban and industrial activities in the coastal regions, and to offshore waste disposal. These anthropogenic releases occur through river, atmosphere, and direct discharges, and contribute to the contamination of seas by metals (OSPAR, 2010). Trace elements can be essential or non-essential for living organisms. Essential trace elements, such as $\mathrm{Zn}, \mathrm{Fe}, \mathrm{Cu}$, Se, or $\mathrm{Cr}$, are part of protein complexes (metalloproteins), are required for enzymatic activities, and can play structural roles in connective tissue and cell membranes (Bryan et al., 2007). They are thus beneficial for living organisms at low concentrations, but can become toxic at higher concentrations, above a certain threshold. The essentiality of other trace elements, like $\mathrm{Ni}$ and $\mathrm{V}$, has also been well established for various biological functions, but the information on their optimal and deficient concentrations is limited. Non-essential trace elements, such as $\mathrm{Hg}, \mathrm{Cd}$, and $\mathrm{Pb}$, are not required for physiological processes and are considered toxic even at very low levels (AMAP, 2005; Wolfe et al., 1998). Although $\mathrm{Ca}$ is an essential macro-element, it was also included in this study to assess the potential interactions with $\mathrm{Pb}$ and $\mathrm{Cd}$. Indeed, $\mathrm{Pb}$ binds tightly to both $\mathrm{Ca}$ and $\mathrm{Zn}$ sites in proteins and alters their activity (Godwin, 2001). Exposure to Cd may also cause bone demineralization and skeletal damage due to the hyperexcretion of Ca (AMAP, 2005).

Grey seals have life history characteristics that make them a good 'model' in which to study the effects of lactation and fasting on the levels of trace elements in pinnipeds. In this paper, we investigated the changes in levels of 11 elements $(\mathrm{Ca}, \mathrm{Cd}, \mathrm{Cr}, \mathrm{Cu}, \mathrm{Fe}, \mathrm{Hg}, \mathrm{Ni}$, $\mathrm{Pb}, \mathrm{Se}, \mathrm{V}$, and $\mathrm{Zn}$ ) in a longitudinal study on 21 grey seal mother-pup pairs during the lactation period and a part of the post-weaning fast period. The main objectives were to (1) investigate the effect of physiological processes on the distribution of trace elements in different tissues (blood, blubber, and hair) of mothers and their offspring, and (2) characterize the mineral content in grey seal milk and to assess changes in levels during lactation. To the best of our knowledge, this paper represents the first assessment of the levels of trace element contamination in UK grey seals from the North Sea.

\section{Materials and methods}

\subsection{Field techniques}

This study was performed on the Isle of May, Scotland $\left(56^{\circ} 11^{\prime} \mathrm{N}, 2^{\circ} 33^{\prime} \mathrm{W}\right.$; Fig. 1), during the 2008 breeding season (October-December). On arrival at the colony, females were monitored and birth dates of pups were recorded by daily observations of the breeding areas. Twenty-one known mother-pup pairs were captured in early lactation (at 2-4 days postpartum) and

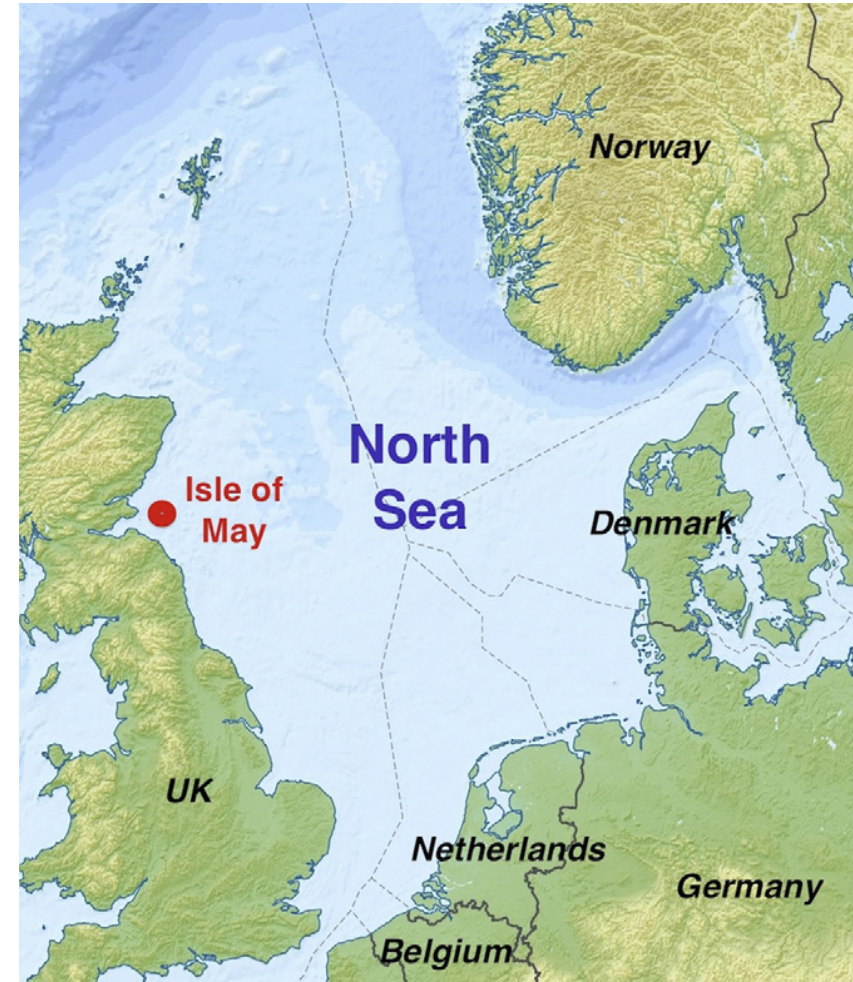

Fig. 1. Location of the grey seal colony on the Isle of May (Scotland), in the North Sea.

recaptured approximately 13 days later in late lactation (at 15-17 days postpartum). Samples of maternal blubber, blood, milk, as well as pup blood were collected from pairs at each capture. Mothers were immobilized with an intramuscular injection of Zoletil 100 ( $1 \mathrm{ml}$ per $100 \mathrm{~kg}$ of estimated body mass; Virbac, UK, Ltd.) and immobilization was maintained with intravenous injections of Zoletil if necessary. Pups were restrained and captured manually. Blood samples were obtained from the extradural vein of mothers and pups. Whole blood samples were collected in $6 \mathrm{ml}$ Vacutainer $^{\mathrm{TM}}$ plastic tubes treated with $\mathrm{K}_{2}$ EDTA anticoagulant (Fisher Scientific International) and certified for trace element analyses (throughout the text, 'blood' refers to whole blood). Milk samples were collected from each female $5 \mathrm{~min}$ after a $1 \mathrm{ml}$ intravenous injection of oxytocin (Leo Laboratories, Dublin, Ireland) to stimulate release of the milk. Milk was expressed from the teat using a clean cut-off syringe and was transferred to two $5 \mathrm{ml}$ plastic tubes. A blubber biopsy was taken at both captures from the lateral pelvic area after a subcutaneous injection of local anaesthetic (Lidocaine, $3 \mathrm{ml}$ ). A small part of the anaesthetized area was cleaned with alcohol. A small incision was then made and a blubber biopsy, extending the full depth of the blubber layer, was taken with a $6 \mathrm{~mm}$ biopsy punch (Acu-Punch ${ }^{\circledR}$, Acuderm). Blubber biopsies were stored in plastic tubes. Mothers' hair and pups' lanugo were collected only once during lactation. Hair and lanugo are inert tissues in which trace elements are not considered bioavailable (Wenzel et al., 1993). Concentrations in these tissues reflect concentrations in internal tissues from circulating levels of elements at the moment of their growth, i.e., during the previous moult for mother's hair or the foetal development for pup's lanugo. In mothers, a patch of hair (approximately $15 \mathrm{~cm} \times 15 \mathrm{~cm} ; \sim 3 \mathrm{~g}$ ) was shaved from the dorsal midline region, in the lower part, using a "oneuse" stainless steel blade. Lanugo of pups was simply plucked from the dorsal midline region when they began moulting, at the second capture. Hair and lanugo were placed in a polyethylene bag. Antibiotic was given to mother with a prophylactic intramuscular 
Table 1

Biometry (mean \pm SD; range) of grey seal mothers and pups at different stages of lactation and development (T1, early lactation; T2, late lactation; T3, early post-weaning fast; $\mathrm{T} 4$, middle post-weaning fast).

\begin{tabular}{lllll}
\hline & & $n$ & Mass $(\mathrm{kg})$ & Standard length $(\mathrm{cm})$ \\
\hline Mothers & T1 & 21 & $164 \pm 27(125-232)$ & $168 \pm 8(148-180)$ \\
Pups & 21 & $123 \pm 22(90-182)$ & $165 \pm 8(150-182)$ \\
& T2 & 21 & $18 \pm 3(12-24)$ & $126 \pm 10(111-144)$ \\
& T1 & 21 & $39 \pm 8(24-50)$ & \\
T2 & 15 & $39 \pm 6(30-48)$ & \\
T3 & 11 & $36 \pm 5(27-44)$ & \\
\hline
\end{tabular}

Lactation duration (day): $19 \pm 2$ (16-23). Pup sex ratio (female:male): 48:52.

injection of Oxytetrin (oxytetracycline, $10-15 \mathrm{ml}$ ). Sixteen of the 21 pups were recaptured once or twice after weaning (around days 19 and 30 postpartum) to collect blood and blubber samples, following the same procedure as described above with the mothers. A $4 \mathrm{~mm}$ instead of a $6 \mathrm{~mm}$ biopsy punch was used to sample blubber from weaned pups. At each capture, a measuring tape was used to record mother's nose to tail length and axial girth. Mothers were weighed using a scale (Salter Industrial Measurements Ltd., West Bromwich, UK; capacity $500 \pm 0.2 \mathrm{~kg}$ ) suspended from a tripod, and suckling and weaned pups were weighed $\pm 0.5 \mathrm{~kg}$ on a spring balance (Salter Industrial Measurements Ltd., West Bromwich, UK) at each sampling. The pup's sex was determined. Biometric data on the mother-pup pairs are summarized in Table 1.

Mothers and pups were individually identified at the first capture with a paint mark to aid recapture. After each procedure, the mother and pup were released and monitored until the female had regained mobility. All capture and handling procedures were performed under UK Home Office project licence \#60/3303 and conformed to the Animals (Scientific Procedures) Act 1986. All samples were stored at $-20^{\circ} \mathrm{C}$ in the laboratory until analysis.

\subsection{Sample preparation}

Prior to analysis, blood samples were freeze-dried, then ground with a mortar and pestle into powder. Water content was determined. After thawing, maternal hair and pup lanugo were washed ultrasonically with reagent grade acetone (acetone for analysis, EMSURE $^{\circledR}$, Merck) and were rinsed repeatedly with $18.2 \mathrm{M} \Omega \mathrm{cm}$ deionized water to remove exogenous contaminants, according to the method recommended by the International Atomic Energy Agency (Chatt and Katz, 1988). Hair and lanugo samples were then freeze-dried for $24 \mathrm{~h}$.

Blubber of seals is stratified in chemically distinct layers, each having a different function: (1) the outer layer is primarily structural and thermoregulatory, (2) the inner layer is metabolically active with a fatty acid composition that is strongly affected by lipid mobilization/deposition, and (3) the middle layer is a storage site (Strandberg et al., 2008). Mobilization of elements was therefore investigated in the inner and outer blubber layers when it was possible. Blubber biopsies of mothers were large enough to cut them in two equal parts separating the inner and outer blubber layers. Blubber biopsies from weaned pups were analysed whole.

\subsection{Element analyses}

Concentrations of elements $(\mathrm{Cd}, \mathrm{Cr}, \mathrm{Cu}, \mathrm{Fe}, \mathrm{Ni}, \mathrm{Pb}, \mathrm{Se}, \mathrm{V}, \mathrm{Zn}$, and $\mathrm{Ca}$ ) were measured in blood, blubber, milk, hair and lanugo of 21 mother-pup pairs during the breeding season. Approximately $0.2 \mathrm{~g}$ of freeze-dried blood, $0.25 \mathrm{~g}$ of washed and freeze-dried hair or lanugo, and $0.5 \mathrm{ml}$ of thawed milk were weighed to the nearest $0.0001 \mathrm{~g}$. Thawed blubber sub-samples ( $\sim 0.2 \mathrm{~g}$, mothers) or the whole biopsy (weaned pups) were weighed. All these samples were subjected to microwave-assisted digestion in Teflon ${ }^{\mathrm{TM}}$ vessels with $4 \mathrm{ml} \mathrm{HNO}_{3}$ (65\%), $1 \mathrm{ml} \mathrm{H} \mathrm{H}_{2} \mathrm{O}_{2}$ (30\%) and $3 \mathrm{ml}$ of $18.2 \mathrm{M} \Omega \mathrm{cm}$ deionized water. After cooling, samples were diluted to $50 \mathrm{ml}$ with $18.2 \mathrm{M} \Omega \mathrm{cm}$ deionized water in a volumetric flask. Concentrations of $\mathrm{Cd}, \mathrm{Cr}, \mathrm{Cu}, \mathrm{Fe}, \mathrm{Ni}, \mathrm{Pb}, \mathrm{Se}, \mathrm{V}, \mathrm{Zn}$ and $\mathrm{Ca}$ were determined by inductively coupled plasma mass spectroscopy (ICP-MS, PerkinElmer, Sciex, DCR 2). Multiple-elements $\left({ }^{74} \mathrm{Ge},{ }^{103} \mathrm{Rh},{ }^{209} \mathrm{Bi}\right.$, and ${ }^{69} \mathrm{Ga}$ ) internal standards (CertiPUR ${ }^{\circledR}$, Merck) were added to each sample and calibration standard solutions. Quality control and quality assurance for ICP-MS included field blanks, method blanks, certified reference materials (CRMs) - Seronorm L-3, DOLT-3, NIES13 , and BCR-063. Certified reference material recovery (\%) and the instrumental quantification limits for each element are listed in Table 2. Cadmium was not detected in blood, blubber, and milk. $\mathrm{Ni}$ and Se were below the limit of quantification in all blood and blubber samples, respectively. $\mathrm{V}, \mathrm{Cr}$, and $\mathrm{Pb}$ were below the limit of quantification in some blood samples $(29 \%, 13 \%$, and $11 \%$ of analysed samples, respectively). Data below quantifiable limits were not subjected to further statistical analyses. Reported concentrations for all elements in blood, blubber and milk are expressed on a wet weight basis in $\mathrm{mg} / \mathrm{kg}$, whereas concentrations for hair and lanugo are expressed on a dry weight basis in $\mathrm{mg} / \mathrm{kg}$.

\subsection{Total $\mathrm{Hg}$ analysis}

Approximately $30-50 \mathrm{mg}$ of freeze-dried blood and 1-4 mg of hair and lanugo were accurately weighed and loaded into quartz boats. The masses were recorded to the nearest $0.01 \mathrm{mg}$. After thawing, milk samples were homogenized and aliquots of 30-40 $\mu \mathrm{l}$ were weighed and loaded into quartz boats. Because $\mathrm{Hg}$ levels in milk were low, 3-4 quartz boats were concentrated to obtain the $\mathrm{Hg}$ value of one sample. Total $\mathrm{Hg}(\mathrm{THg})$ concentrations were determined by atomic absorption spectroscopy (AAS, Direct Mercury Analyzer DMA-80, Milestone). The method has been validated for solid samples using US EPA Method 7473. Quality assurance methods included evaluating by measuring blanks, duplicates, and CRMs - Seronorm L-3 and NIES-13 with every 10 samples (Table 2 ). Digested samples of blubber were used for trace element analysis, including THg analysis, to assure sample homogeneity. However, THg could not be determined in blubber samples because levels were below the limit of quantification after the microwave-assisted digestion and the successive dilution ( $\mathrm{THg}<0.150 \mathrm{mg} / \mathrm{kg}$ ww blubber).

\subsection{Statistical analyses}

A Kolmogorov-Smirnov test was used to determine whether data departed from normality. The variables were not normally distributed and non-parametric tests were used for statistical analyses. To evaluate changes in element levels during breeding season in tissues, Wilcoxon signed-rank tests were used to compare means at different sampling times. Similarly, difference between mothers and pups in blood and hair levels were tested using Wilcoxon signed-rank tests. The Spearman's rank correlation coefficient was 
Table 2

Certified reference material recoveries $(\%, n=10)$ and instrumental quantification limits (IQL, ppb) for element analyses.

\begin{tabular}{|c|c|c|c|c|c|c|}
\hline \multirow[t]{2}{*}{ Element } & \multirow[t]{2}{*}{ Method } & \multirow[t]{2}{*}{ IQL } & \multicolumn{4}{|c|}{ Certified reference material recovery (\%) } \\
\hline & & & Seronorm L-3a & DOLT- $3^{b}$ & NIES-13c & BCR-063 \\
\hline $\mathrm{Ca}$ & ICP-MS & 0.534 & 99 & n.c. & 90 & 90 \\
\hline $\mathrm{Cd}$ & ICP-MS & 0.002 & 98 & 99 & 90 & n.c. \\
\hline $\mathrm{Cr}$ & ICP-MS & 0.002 & 107 & 84 & n.c. & n.c. \\
\hline $\mathrm{Cu}$ & ICP-MS & 0.009 & 97 & 104 & 90 & 106 \\
\hline $\mathrm{Fe}$ & ICP-MS & 0.042 & 98 & 99 & 87 & 81 \\
\hline $\mathrm{Ni}$ & ICP-MS & 0.022 & n.d. & 100 & n.c. & n.c. \\
\hline $\mathrm{Pb}$ & ICP-MS & 0.005 & 98 & 109 & 94 & n.d. \\
\hline $\mathrm{Se}$ & ICP-MS & 0.108 & 109 & 96 & 76 & n.d. \\
\hline V & ICP-MS & 0.001 & 93 & n.c. & 76 & n.c. \\
\hline Zn & ICP-MS & 0.032 & 91 & 103 & 84 & 75 \\
\hline $\mathrm{Hg}$ & AAS & 0.898 & 85 & n.d. & 95 & n.c. \\
\hline
\end{tabular}

n.c., not certified value; n.d., not determined.

a Seronorm Level 3, Trace elements whole blood (Sero, Billingstad, Norway)

b DOLT-3, Dogfish liver (National Research Council of Canada, NRCC, Ontario, Canada)

c NIES-13, Human hair no. 13 (National Institute for Environmental Studies, NIES, Ibaraki, Japan)

BCR-063, Skim milk powder (Institute for Reference Materials and Measurements, IRMM, Geel, Belgium)

used to test correlations between two variables. Statistical analysis of the data was performed using Statistica software (Statsoft Inc., Version 10) and $p<0.05$ was considered as significant (with $\alpha=0.05$ ). Results are presented as mean (median) \pm standard deviation (SD), range.

\section{Results}

Results of elements in blood, milk, blubber, and hair of grey seals at different stages of lactation and development are summarized in Table 3. Element concentrations were determined in blubber sub-samples (inner and outer layers) in mothers, and in the whole biopsies in weaned pups. To compare easily values between mothers and weaned pups, mean concentrations in the whole biopsy in mothers were also calculated from concentrations in blubber subsamples (Table 3). Element levels in grey seal mothers and pups in early lactation are first described and compared (Sections 3.1 and 3.2). Changes in concentrations during lactation and post-weaning fast are then examined (Section 3.3). The last section assesses the relationships between elements, tissues, and biometric parameters of grey seals (Section 3.4).

\subsection{Levels of trace elements in grey seal females from early lactation}

The lactating female grey seals from the Isle of May showed element concentrations in blood that decreased according to the following pattern: $\mathrm{Fe}>\mathrm{Ca}>\mathrm{Zn}>\mathrm{Se}>\mathrm{Cu}>\mathrm{Hg}>\mathrm{Pb}>\mathrm{Cr}>\mathrm{V}$ (Table 3). Mercury had the greatest levels of the non-essential metals measured in blood, with $0.083 \mathrm{mg} / \mathrm{kg}$ ww in early lactation. The variation among individuals in blood concentrations ranged from $5 \%$ to $109 \%$ according to element, with the lowest variability for $\mathrm{Ca}$ and Fe levels (5-12\%) and the greatest for Pb and V levels (43-109\%, Table 4).

Element concentrations in maternal blubber followed the sequence: $\mathrm{Fe}>\mathrm{Ca}>\mathrm{Zn}>\mathrm{Ni}>\mathrm{Cu}>\mathrm{Cr}>\mathrm{Pb}>\mathrm{V}$ (Table 3). Iron, $\mathrm{V}$, and $\mathrm{Pb}$ levels showed a very important variability in blubber (up to $84 \%$, $127 \%$, and $144 \%$, respectively; Table 4 ). Levels of $\mathrm{Ni}, \mathrm{Cr}, \mathrm{Pb}$, and $\mathrm{V}$ in blubber were greater than those in blood (Table 3). Results in the blubber sub-samples of grey seal mothers showed no significant difference in concentrations between inner and outer blubber in early lactation (for all elements, $p>0.05$, Wilcoxon signed-rank tests).

In contrast with blood and blubber, all element concentrations in the maternal hair were above the limit of quantification. Element concentrations in maternal hair decreased according to the following pattern: $\mathrm{Ca}>\mathrm{Zn}>\mathrm{Fe}>\mathrm{Hg}>\mathrm{Cu}>\mathrm{Se}>\mathrm{V}>\mathrm{Pb}>\mathrm{Ni}>\mathrm{Cd}>\mathrm{Cr}$ (Table 3).

All elements, except $\mathrm{Cd}$, were detected in the milk and followed the sequence: $\mathrm{Ca}>\mathrm{Fe}>\mathrm{Zn}>\mathrm{Se}>\mathrm{Cu}>\mathrm{Ni}>\mathrm{Pb}>\mathrm{Hg}>\mathrm{Cr}>\mathrm{V}$. Levels of $\mathrm{Ca}, \mathrm{Zn}, \mathrm{Ni}, \mathrm{Pb}, \mathrm{Cr}$, and $\mathrm{V}$ were greater in milk than in maternal blood, while $\mathrm{Fe}, \mathrm{Cu}, \mathrm{Se}$, and $\mathrm{Hg}$ levels in milk were less than those in blood (Table 3). Levels of $\mathrm{Ni}, \mathrm{Cr}, \mathrm{Pb}$, and $\mathrm{V}$ in milk were less than those in blubber (Table 3). The proportions of each element in blood, blubber, hair, and milk of lactating female grey seals are shown in Fig. A1.

\subsection{Levels of trace elements in grey seal pups from early lactation}

All elements, except $\mathrm{Ni}$ and $\mathrm{Cd}$, were detected and quantified in pup blood (Table 3). Element concentrations in pup blood decreased according to the same pattern as mothers $(\mathrm{Fe}>\mathrm{Ca}>\mathrm{Zn}>\mathrm{Se}>\mathrm{Cu}>\mathrm{Hg}>\mathrm{Pb}>\mathrm{Cr}>\mathrm{V})$. Levels of $\mathrm{Fe}, \mathrm{Ca}, \mathrm{Zn}$, and $\mathrm{Cu}$ in pup blood rose from $90 \%$ to $116 \%$ of the maternal levels in early lactation (at 2-4 days postpartum; Fig. 2). Levels of $\mathrm{Pb}, \mathrm{Cr}$, and $\mathrm{V}$ in blood were very low $(<0.012 \mathrm{mg} / \mathrm{kg} \mathrm{ww})$; nevertheless pup levels in early lactation were similar to maternal levels for $\mathrm{Pb}$ or even greater than maternal levels for $\mathrm{V}$ and $\mathrm{Cr}$ (177\% and $144 \%$ of the maternal value, respectively; Fig. 2). In contrast, blood Se level in pups in early lactation was much less than that in mothers at the same time ( $\sim 38 \%$ of the maternal value), and $\mathrm{Hg}$ level in pups was half that of maternal level (Fig. 2).

All elements were detected in pup lanugo and followed the sequence: $\mathrm{Ca}>\mathrm{Zn}>\mathrm{Fe}>\mathrm{Hg}>\mathrm{Se}>\mathrm{Cu}>\mathrm{Pb}>\mathrm{Ni}>\mathrm{V}>\mathrm{Cr}>\mathrm{Cd}$ (Table 3). Only $\mathrm{Zn}$ level was greater in lanugo than in maternal hair (122 vs. $101 \mathrm{mg} / \mathrm{kg} \mathrm{dw}$; Fig. 3). All other elements showed lower concentrations in lanugo (for all $p \leq 0.001$, Wilcoxon signed-rank tests; Fig. 3 ). Nevertheless, $\mathrm{Se}, \mathrm{Cu}$, and $\mathrm{Hg}$ levels in lanugo were quite substantial and showed $76 \%, 73 \%$, and $62 \%$ of the maternal value, respectively (Fig. 3).

The proportions of each element in pup blood and lanugo are given in Fig. A1.

\subsection{Changes of trace element concentrations in blood, milk, and blubber throughout lactation and post-weaning fast}

During lactation, concentrations varied significantly in maternal blood for Fe, Zn, Se, and Hg: while Fe and Se levels decreased, $\mathrm{Zn}$ and $\mathrm{Hg}$ levels increased between early and late lactation (Table 5). In pup blood, most element concentrations increased during lactation. Only $\mathrm{Fe}$ and $\mathrm{Hg}$ pup levels decreased between early and late lactation, up to $50 \%$ for $\mathrm{Hg}$ (Table 5). At weaning, 
S. Habran et al. / Aquatic Toxicology 126 (2013) 455-466

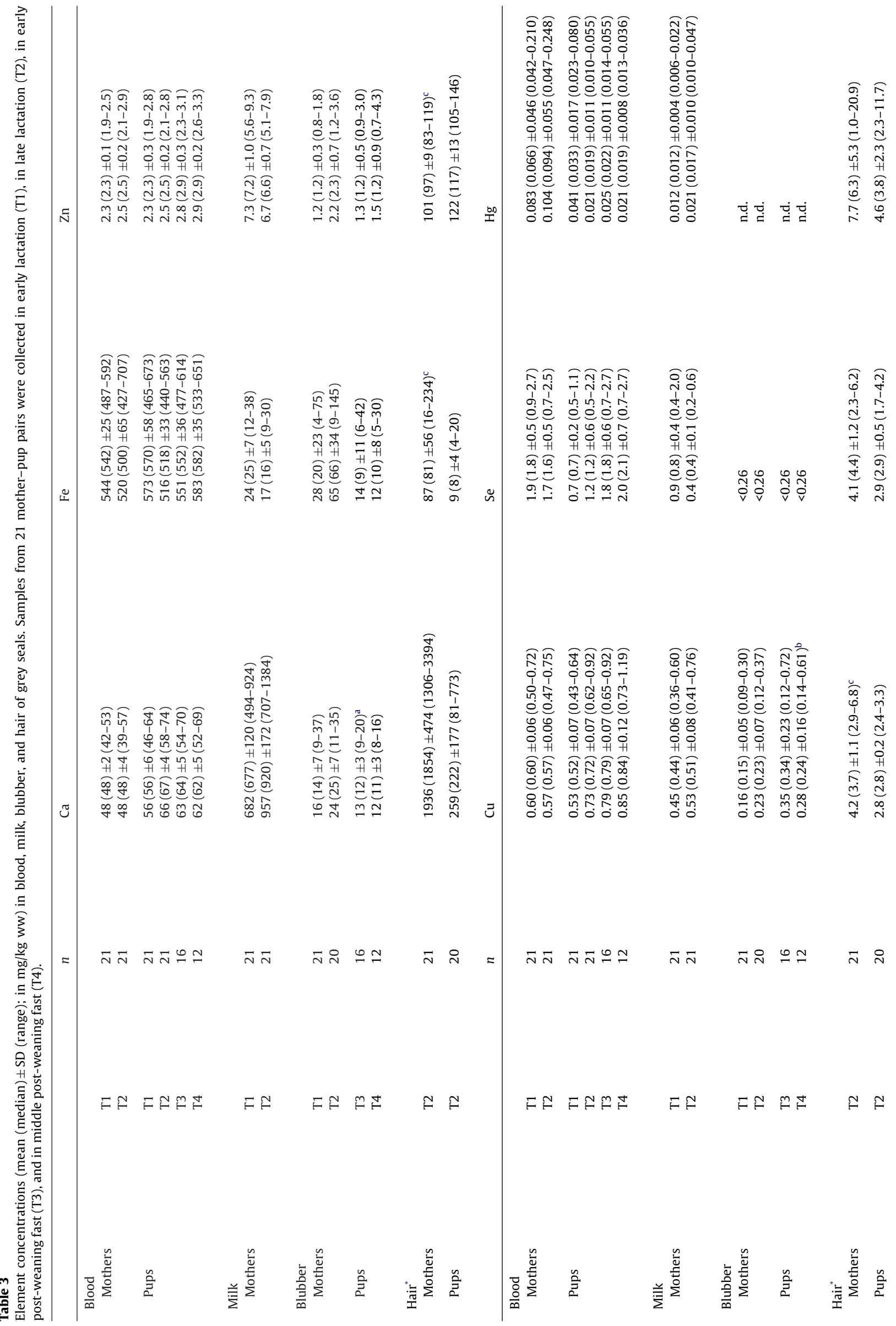




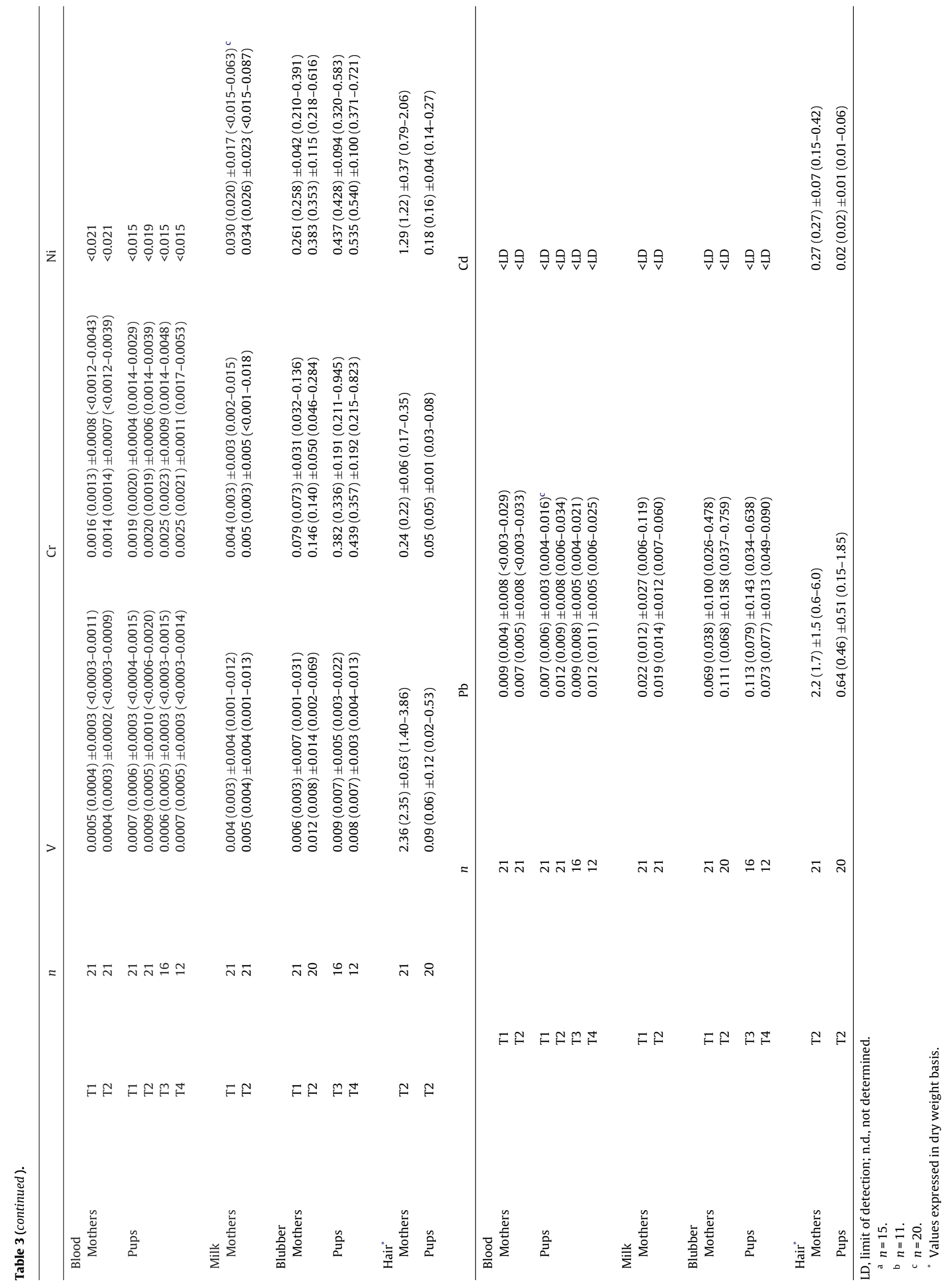


Table 4

Variation among individuals in element concentrations in blood, milk, blubber, and hair of grey seals. Coefficients of variation are expressed in percentage.

\begin{tabular}{|c|c|c|c|c|c|c|c|c|c|c|c|c|c|c|}
\hline \multirow[b]{4}{*}{$n$} & \multicolumn{6}{|c|}{ Blood } & \multirow{2}{*}{\multicolumn{2}{|c|}{$\frac{\text { Milk }}{\text { Mothers }}$}} & \multicolumn{4}{|c|}{ Blubber } & \multicolumn{2}{|l|}{ Hair } \\
\hline & \multicolumn{2}{|c|}{ Mothers } & \multicolumn{4}{|c|}{ Pups } & & & \multicolumn{2}{|c|}{ Mothers } & \multicolumn{2}{|c|}{ Pups } & \multirow{2}{*}{$\begin{array}{l}\text { Mothers } \\
\text { T2 }\end{array}$} & \multirow{2}{*}{$\begin{array}{l}\text { Pups } \\
\text { T2 }\end{array}$} \\
\hline & $\mathrm{T} 1$ & $\mathrm{~T} 2$ & $\mathrm{~T} 1$ & $\mathrm{~T} 2$ & T3 & $\mathrm{T} 4$ & $\mathrm{~T} 1$ & $\mathrm{~T} 2$ & $\mathrm{~T} 1$ & $\mathrm{~T} 2$ & T3 & $\mathrm{T} 4$ & & \\
\hline & 21 & 21 & 21 & 21 & 16 & 12 & 21 & 21 & 21 & 20 & 16 & 12 & 21 & 20 \\
\hline $\mathrm{Ca}$ & 5 & 8 & 10 & 6 & 8 & 9 & 18 & 18 & 45 & 29 & 23 & 23 & 24 & 68 \\
\hline $\mathrm{Fe}$ & 5 & 12 & 10 & 6 & 6 & 6 & 28 & 31 & 84 & 52 & 82 & 65 & 64 & 41 \\
\hline $\mathrm{Zn}$ & 6 & 9 & 11 & 8 & 9 & 7 & 13 & 11 & 21 & 32 & 39 & 65 & 9 & 11 \\
\hline $\mathrm{Cu}$ & 9 & 10 & 12 & 9 & 9 & 14 & 14 & 15 & 34 & 30 & 64 & 56 & 27 & 7 \\
\hline $\mathrm{Se}$ & 28 & 30 & 23 & 49 & 31 & 34 & 47 & 22 & & & & & 28 & 18 \\
\hline $\mathrm{Hg}$ & 56 & 53 & 42 & 54 & 46 & 37 & 29 & 46 & & & & & 69 & 51 \\
\hline V & 61 & 58 & 47 & 51 & 55 & 52 & 84 & 77 & 127 & 120 & 60 & 38 & 27 & 127 \\
\hline $\mathrm{Cr}$ & 53 & 47 & 21 & 28 & 36 & 43 & 64 & 94 & 39 & 34 & 50 & 44 & 23 & 22 \\
\hline $\mathrm{Ni}$ & & & & & & & 57 & 67 & 16 & 30 & 22 & 19 & 29 & 20 \\
\hline $\mathrm{Pb}$ & 88 & 109 & 47 & 66 & 48 & 43 & 122 & 64 & 144 & 143 & 127 & 18 & 67 & 79 \\
\hline $\mathrm{Cd}$ & & & & & & & & & & & & & 27 & 52 \\
\hline
\end{tabular}

T1, early lactation; T2, late lactation; T3, early post-weaning fast; T4, middle post-weaning fast.

\section{Blood}

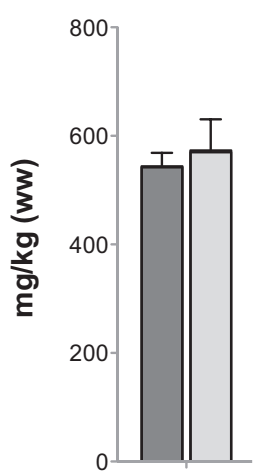

$\mathrm{Fe}^{*}$

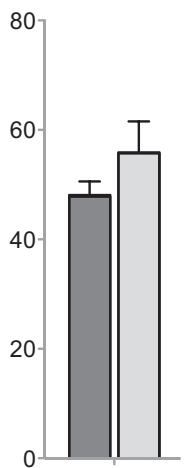

$\mathrm{Ca}^{*}$

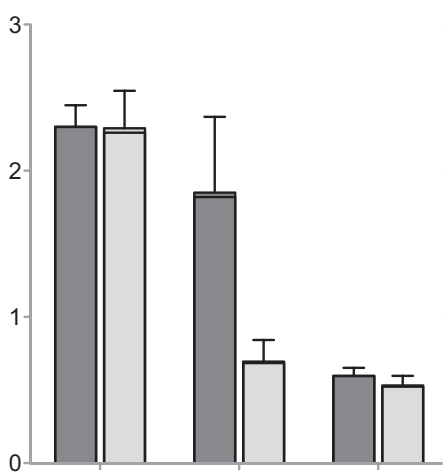

$\mathrm{Zn} \mathrm{Se*}$

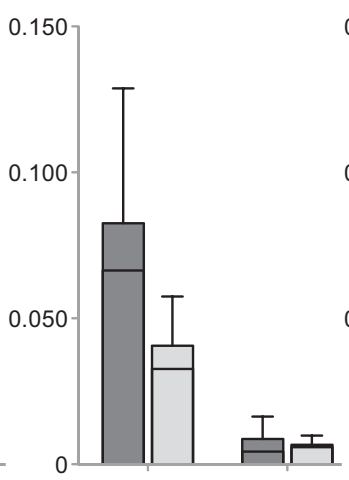

$\mathrm{Hg}^{*}$

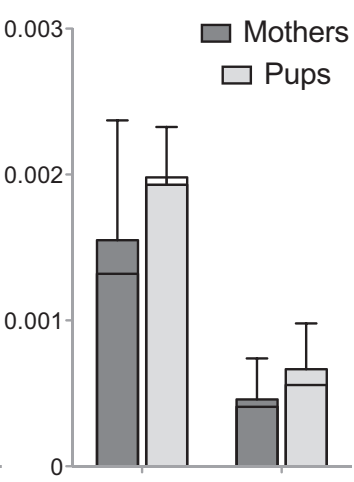

$\mathrm{Cr}^{*} \quad \mathrm{~V}^{*}$

Fig. 2. Element concentrations in blood of grey seals. Comparison of levels (mean $\pm \mathrm{SD} ; \mathrm{mg} / \mathrm{kg}$ ww) between mothers (dark grey bars) and suckling pups (light grey bars) in early lactation. Black line in bars represents the median. ${ }^{*}$ indicates significant difference between maternal and pup values ( $p<0.05$, Wilcoxon signed-rank tests).

$\mathrm{Ca}$ and $\mathrm{V}$ levels of pup blood decreased, Pb levels remained stable, whereas the other element levels increased. Concentrations did not vary or only slightly during the first half of post-weaning fast (Table 5).

Milk levels of $\mathrm{Ca}, \mathrm{Fe}, \mathrm{Zn}, \mathrm{Cu}$, Se, and $\mathrm{Hg}$ varied between the beginning and the end of lactation (Table 5). Level of Se fell to $48 \%$ of the value in early lactation, while level of $\mathrm{Hg}$ in milk increased from 0.012 to $0.021 \mathrm{mg} / \mathrm{kg}$ ww between early and late lactation (Table 5). Changes in the milk water content during lactation (from approximately $40 \%$ in early lactation to $30 \%$ in late lactation in this study) may affect element concentrations. However, when values in $\mathrm{mg} / \mathrm{kg}$ ww were converted in dry weight basis, similar trends as those in Table 5 were observed for most of trace elements.

\section{Hair \& lanugo}
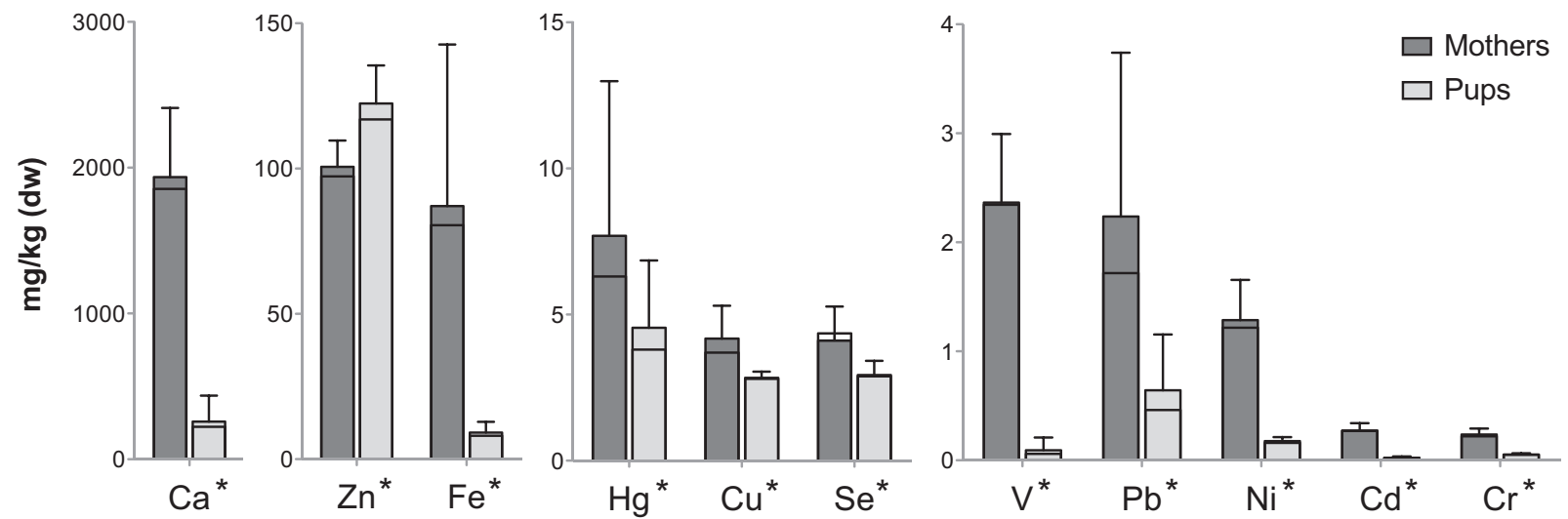

Fig. 3. Element concentrations in hair of grey seals. Comparison of levels (mean $\pm \mathrm{SD} ; \mathrm{mg} / \mathrm{kg} \mathrm{dw}$ ) between maternal hair (dark grey bars) and pup lanugo (light grey bars). Black line in bars represents the median. * indicates significant difference between maternal and pup values $(p \leq 0.001$, Wilcoxon signed-rank tests) 
Table 5

Comparisons of element concentrations throughout lactation and development: results of Wilcoxon signed-rank tests ( $p$-value) and ratios ([ $\left.\left.\mathrm{T}_{x+1}\right] /\left[\mathrm{T}_{x}\right] \times 100\right)$ noted when concentrations were significantly different (n.s., non significant).

\begin{tabular}{|c|c|c|c|c|c|c|c|}
\hline \multirow[b]{4}{*}{$n$} & \multicolumn{4}{|l|}{ Blood } & \multirow{3}{*}{$\begin{array}{l}\text { Milk } \\
\text { Mothers } \\
\text { T2/T1 }\end{array}$} & \multicolumn{2}{|l|}{ Blubber } \\
\hline & Mothers & Suckling pups & Pups & Weaned pups & & Mothers & Weaned pups \\
\hline & $\mathrm{T} 2 / \mathrm{T} 1$ & $\mathrm{~T} 2 / \mathrm{T} 1$ & T3/T2 & $\mathrm{T} 4 / \mathrm{T} 3$ & & $\mathrm{~T} 2 / \mathrm{T} 1$ & $\mathrm{~T} 4 / \mathrm{T} 3$ \\
\hline & 21 & 21 & 16 & 12 & 21 & 20 & 12 \\
\hline $\mathrm{Ca}$ & n.s. & $p<0.001,119 \%$ & $p=0.011,96 \%$ & n.s. & $p<0.001,144 \%$ & $p=0.002,177 \%$ & n.s. ${ }^{\text {b }}$ \\
\hline $\mathrm{Fe}$ & $p=0.033,96 \%$ & $p<0.001,91 \%$ & $p=0.001,107 \%$ & $p=0.004,105 \%$ & $p=0.002,77 \%$ & $p=0.001,442 \%$ & n.s. \\
\hline $\mathrm{Zn}$ & $p=0.001,110 \%$ & $p=0.003,109 \%$ & $p=0.001,110 \%$ & n.s. & $p=0.023,93 \%$ & $p<0.001,186 \%$ & n.s. \\
\hline $\mathrm{Cu}$ & n.s. & $p<0.001,138 \%$ & $p=0.001,112 \%$ & n.s. & $p<0.001,119 \%$ & $p=0.001,152 \%$ & n.s. ${ }^{b}$ \\
\hline $\mathrm{Se}$ & $p<0.001,89 \%$ & $p=0.001,175 \%$ & $p<0.001,167 \%$ & n.s. & $p<0.001,48 \%$ & & \\
\hline $\mathrm{Hg}$ & $p<0.001,128 \%$ & $p<0.001,52 \%$ & $p<0.001,120 \%$ & $p=0.002,91 \%$ & $p<0.001,174 \%$ & & \\
\hline $\mathrm{V}$ & n.s. & $p=0.010,149 \%$ & $p=0.001,66 \%$ & n.s. & n.s. & $p=0.011,364 \%$ & n.s. \\
\hline $\mathrm{Cr}$ & n.s. & n.s. & $p=0.020,132 \%$ & n.s. & n.s. & $p<0.001,222 \%$ & n.s. \\
\hline $\mathrm{Ni}$ & & & & & n.s. ${ }^{\mathrm{a}}$ & $p<0.001,148 \%$ & n.s. \\
\hline $\mathrm{Pb}$ & n.s. & $p<0.001,172 \%$ & n.s. & $p=0.034,143 \%$ & n.s. & $p=0.003,212 \%$ & n.s. \\
\hline
\end{tabular}

T1, early lactation; T2, late lactation; T3, early post-weaning fast; T4, middle post-weaning fast.

a $n=20$.

Maternal concentrations of all elements in whole blubber increased between the beginning and the end of lactation. Depending on the element, levels in late lactation rose to $148-442 \%$ of the value in early lactation (Table 5). Results in the blubber subsamples of grey seal mothers showed that concentrations increased between early and late lactation both in inner and outer blubber. However, magnitude of increase was more important in inner blubber for $\mathrm{Ca}, \mathrm{Fe}, \mathrm{Zn}$, and $\mathrm{Cu}$. Consequently, concentrations of $\mathrm{Ca}, \mathrm{Fe}, \mathrm{Zn}$, and $\mathrm{Cu}$ in late lactation were greater in inner than in outer blubber (Table 6), whereas concentrations of $\mathrm{V}, \mathrm{Cr}, \mathrm{Ni}$, and $\mathrm{Pb}$ in late lactation were similar in inner and outer blubber ( $p>0.05$, Wilcoxon signed-rank tests). In contrast, there was no change of concentration in blubber of weaned pups during the early post-weaning fast period (Table 5). Levels of $\mathrm{Cr}$ and $\mathrm{Ni}$ in blubber were much greater in weaned pups than in mothers (Table 3).

\subsection{Relationships between elements, tissues, and biometric parameters}

Correlations between trace elements in the different tissues are given in Table 7. In blood, only Fe and $\mathrm{Zn}$ concentrations were positively correlated. Interestingly, $\mathrm{Ni}, \mathrm{Cr}, \mathrm{Pb}$, and $\mathrm{V}$ showed a significant relationship with each other, both in milk and blubber (Table 7 and Fig. 4 for milk). Some correlations were observed between the different tissues. Only $\mathrm{Hg}$ and Se showed a significant positive relationship between hair and blood levels in mothers $(r=0.66$, $p=0.001$ and $r=0.51, p=0.017$, respectively; Spearman's rank correlation coefficient). Blood levels of elements were not significantly correlated to levels in maternal blubber, except for $\mathrm{V}$ in early lactation ( $r=0.59, p=0.004$; Spearman's rank correlation coefficient). Concentrations of Se in maternal blood were positively correlated with concentrations of Se in milk $(r=0.62$ and 0.61 in early and late lactation, respectively, for both $p=0.003$; Spearman's rank correlation coefficient). Concentrations of other elements were not significantly correlated between maternal blood and milk, or only slightly. Levels of $\mathrm{Zn}, \mathrm{Se}, \mathrm{Hg}, \mathrm{Pb}$, and $\mathrm{V}$ in pup blood were correlated to maternal blood levels in early lactation $(r=0.53$, $r=0.71, r=0.78, r=0.63, r=0.59$, respectively, for all correlations $p \leq 0.01$; Spearman's rank correlation coefficient). $\mathrm{Cu}, \mathrm{Se}, \mathrm{Pb}$, and $\mathrm{V}$ showed a slightly positive relationship between lanugo and blood levels in pups (for all $r=0.5$ and $p<0.05$; Spearman's rank correlation coefficient), and $\mathrm{Hg}$ showed a highly significant relationship between levels in these tissues ( $r=0.89$ and $p<0.001$; Spearman's rank correlation coefficient).

The biometric parameters (i.e., mass, length, and axial girth) of grey seal mothers and pups were not significantly correlated with element concentrations in the different tissues $(p>0.05$; Spearman's rank correlation coefficient), or only slightly ( $r>-0.50$ for Fe in blubber in early lactation or for $\mathrm{Hg}$ in milk in late lactation, $p<0.05$ for all; Spearman's rank correlation coefficient). Element concentrations in blood, blubber, and lanugo in pups did not differ between males and females (for all $p>0.05$, Mann-Whitney tests). Relationships between element concentrations and lipid content in the different tissues (blood, blubber, and milk; analyses in Vanden Berghe et al., 2012) were also assessed in mothers and pups. Only concentrations of $\mathrm{Ca}$ and Se were correlated to the lipid content in milk, in early lactation $(r=0.67, p=0.001$ and $r=-0.58, p=0.007$, respectively; Spearman's rank correlation coefficient).

\section{Discussion}

\subsection{Trace element levels in UK grey seals}

\subsubsection{Blood levels}

Blood levels of $\mathrm{Ca}, \mathrm{Fe}, \mathrm{Zn}$, and $\mathrm{Cu}$ found in lactating grey seals from the Isle of May were comparable to those reported in studies of other phocid species (Baraj et al., 2001; Griesel et al., 2008; Kakuschke et al., 2006). As essential elements involved in many functions, blood concentrations of $\mathrm{Ca}, \mathrm{Fe}, \mathrm{Zn}$, and $\mathrm{Cu}$ were homeostatically controlled and their concentrations varied little among all animals of this study. In contrast, blood Se level in this study was the greatest values reported in blood of free-ranging phocids (Griesel et al., 2008; Habran et al., 2011). As with any essential trace

Table 6

Comparisons of $\mathrm{Ca}, \mathrm{Fe}, \mathrm{Zn}$, and Cu concentrations between inner and outer maternal blubber in late lactation (Wilcoxon signed-rank tests).

\begin{tabular}{llll}
\hline & $n$ & Inner $^{\mathrm{a}}$ & Outer $^{\mathrm{a}}$ \\
\hline $\mathrm{Ca}$ & 20 & $29(29) \pm 11(12-50)$ & $21(20) \pm 7(11-33)$ \\
$\mathrm{Fe}$ & 20 & $87(84) \pm 54(10-201)$ & $44(43) \pm 22(8-84)$ \\
$\mathrm{Zn}$ & 20 & $2.8(2.8) \pm 1.2(1.1-5.1)$ & $p=0.002$ \\
$\mathrm{Cu}$ & 20 & $0.285(0.286) \pm 0.120(0.117-0.518)$ & $p<0.001$ \\
\hline
\end{tabular}

a Mean (median) $\pm \mathrm{SD}$ (range); in $\mathrm{mg} / \mathrm{kg}$ ww. 
Table 7

Correlations between elements in the different tissues of grey seals (double underlined: $p<0.001$; underlined: $p<0.01$; not underlined: $p<0.05$; Spearman's rank correlation). The different captures were combined for analysis.

\begin{tabular}{|c|c|c|c|c|c|c|}
\hline & Blood & Milk & Blubber of mothers & Blubber of weaned pups & Hair & Lanugo \\
\hline $\mathrm{Ca}$ & & & & $+\mathrm{V}$ & $+\mathrm{Ni}$ & $+\mathrm{Fe}$ \\
\hline $\mathrm{Fe}$ & $+\underline{\underline{Z n}}$ & & & & & $+\overline{\mathrm{Ca}},+\underline{\mathrm{V}},+\underline{\mathrm{Ni}}$ \\
\hline $\mathrm{Zn}$ & $+\underline{\overline{\mathrm{Fe}}}$ & & $+\underline{\mathrm{Cu}},+\underline{\mathrm{Ni}},+\underline{\mathrm{Pb}}$ & & & \\
\hline $\mathrm{Cu}$ & & & $+\overline{\overline{\mathrm{Zn}}},+\overline{\overline{\mathrm{Ni}}},+\overline{\overline{\mathrm{Pb}}}$ & & $-\mathrm{Cr}$ & \\
\hline Se & & & & & $-\mathrm{Ni}$ & \\
\hline V & & $+\underline{\mathrm{Cr}},+\underline{\mathrm{Ni}},+\underline{\mathrm{Pb}}$ & $+\mathrm{Cr},+\mathrm{Ni},+\underline{\mathrm{Pb}}$ & $+\mathrm{Ca}$ & $-\mathrm{Pb}$ & $+\underline{\mathrm{Fe}},+\underline{\mathrm{Ni}}$ \\
\hline $\mathrm{Cr}$ & & $+\underline{\overline{\overline{\mathrm{V}}}},+\underline{\overline{\mathrm{Ni}},}+\underline{\overline{\mathrm{Pb}}}$ & $+\mathrm{V},+\underline{\mathrm{Ni}},+\overline{\mathrm{Pb}}$ & $+\underline{\mathrm{Ni}}$ & $-\mathrm{Cu},+\mathrm{Ni}$ & \\
\hline $\mathrm{Ni}$ & & $+\underline{\overline{\mathrm{V}}},+\underline{\overline{\mathrm{Cr}}},+\underline{\overline{\mathrm{Pb}}}$ & $+\underline{\mathrm{Zn}},+\underline{\mathrm{Cu}},+\mathrm{V},+\underline{\mathrm{Cr}},+\underline{\mathrm{Pb}}$ & $+\underline{\overline{\overline{\mathrm{Cr}}}}$ & $+\underline{\mathrm{Ca}},-\mathrm{Se},+\mathrm{Cr},+\underline{\mathrm{Cd}}$ & $+\underline{\mathrm{Fe}},+\underline{\mathrm{V}}$ \\
\hline $\mathrm{Cd}$ & & & & & $+\overline{\mathrm{Ni}},+\mathrm{Pb} \quad=$ & \\
\hline $\mathrm{Pb}$ & & $+\underline{\underline{\mathrm{V}}},+\underline{\underline{\mathrm{Cr}}},+\underline{\underline{\mathrm{Ni}}}$ & $+\underline{\mathrm{Zn}},+\underline{\underline{\mathrm{Cu}}},+\underline{\mathrm{V}},+\underline{\mathrm{Ni}},+\mathrm{Cr}$ & & $-\overline{\overline{\mathrm{V}},+C d}$ & \\
\hline
\end{tabular}

element, Se can become toxic above a certain threshold. Although marine mammals appear to be less sensitive to dietary organic Se exposure, little information exists about Se toxicity in these animals (Janz et al., 2010). Such levels in pigs have shown reduced reproductive performances (Kim and Mahan, 2001). Overall, blood levels of other trace elements $(\mathrm{V}, \mathrm{Pb}, \mathrm{Cr}, \mathrm{Ni}$, and $\mathrm{Cd})$ in grey seals were in the same range as concentrations reported in phocids (Baraj et al., 2001; Griesel et al., 2008; Kakuschke et al., 2006). Nevertheless, there were some differences in $\mathrm{Pb}$ and $\mathrm{Cr}$ levels in comparison with other seals from the North Sea. Grey seals from this study showed 10 fold higher $\mathrm{Pb}$ levels and 5-8 fold lower $\mathrm{Cr}$ levels than those seen from other phocids from the North Sea (in harbour seals, Griesel et al., 2008; in a grey seal, Kakuschke et al., 2006). Mercury in blood of adult females showed the greatest concentrations of the nonessential metals in this study. However, these $\mathrm{Hg}$ concentrations were less than those encountered for phocids elsewhere (Brookens et al., 2007; Das et al., 2008; Habran et al., 2011). Blood Hg levels in free-ranging harbour seals from the North Sea (Das et al., 2008) were twice as high as those in the present study, reflecting the lower $\mathrm{Hg}$ exposure of grey seals from the Isle of May. As expected, potentially toxic elements (e.g., $\mathrm{V}, \mathrm{Pb}$, and $\mathrm{Hg}$ ) showed wide variations in concentrations for all animals studied (Table 4).

\subsubsection{Hair levels}

Hair contained a greater proportion of non-essential metals in comparison with blood (Fig. A1). Therefore, annual moults represent a significant elimination of these non-essential metals for both sexes. Calcium was the major element present in maternal hair, followed by $\mathrm{Zn}$ and Fe, then $\mathrm{Hg}$ with $7.7 \mathrm{mg} / \mathrm{kg}$ dw. Although an important burden of $\mathrm{Hg}$ seems to be eliminated in hair, this annual loss would represent approximately $17 \%$ of typical total body burdens of $\mathrm{Hg}$ (Agusa et al., 2011). Levels of $\mathrm{Hg}$ were in the same range as values observed in hair of phocids elsewhere (Brookens et al., 2007; Gray et al., 2008; Medvedev et al., 1997), but much less than harbour seals from Germany $(7.7 \mathrm{mg} / \mathrm{kg} \mathrm{dw}$ in grey seals vs. $33.5 \mathrm{mg} / \mathrm{kg} \mathrm{dw}$ in harbour seals, Wenzel et al., 1993). In contrast, $\mathrm{Pb}$ levels in maternal hair were greater $(2.2 \mathrm{mg} / \mathrm{kg} \mathrm{dw})$ than levels reported in most phocids $(0-1.6 \mathrm{mg} / \mathrm{kg} \mathrm{dw}$, Andrade et al., 2007; Medvedev et al., 1997; Wenzel et al., 1993; Yamamoto et al., 1987). Maternal hair also contained high level of $\mathrm{V}(2.4 \mathrm{mg} / \mathrm{kg})$ in comparison with blood, milk, or blubber values. In fact, hair appears to be the primary site of accumulation of $\mathrm{V}$ in phocids: $45 \%$ of the total $\mathrm{V}$ body burden is accumulated in hair (Agusa et al., 2011). Other trace element $(\mathrm{Zn}, \mathrm{Cu}, \mathrm{Se}, \mathrm{Cr}, \mathrm{Cd}$, and $\mathrm{Pb})$ contents in phocid hair represent between $10 \%$ and $18 \%$ of the total body burdens (Agusa et al., 2011).

\subsubsection{Blubber levels}

All elements, except $\mathrm{Cd}$ and Se, were found in maternal blubber. A small amount of blood was sometimes present in blubber biopsies due to associated vascularization. Therefore some elements from blood, especially Fe, may have impacted levels in blubber. This could explain the great variability in Fe levels in blubber. Substantial amounts of $\mathrm{Ni}, \mathrm{Cr}$, and $\mathrm{Pb}$ were found in blubber (Fig. A1). In general, $\mathrm{Ni}, \mathrm{Cr}, \mathrm{Pb}$, and $\mathrm{V}$ seem to be more distributed in lipophilic tissue, like blubber or milk, than the other trace elements. Agusa et al. (2011) showed that $11.5 \%, 26 \%$, and $45 \%$ of total burdens of $\mathrm{V}, \mathrm{Cr}$, and $\mathrm{Pb}$, respectively, were found in the blubber, while only between $0.5 \%$ and $3.5 \%$ of the total burdens of $\mathrm{Zn}, \mathrm{Cu}, \mathrm{Se}$, $\mathrm{Cd}$, and $\mathrm{Hg}$ were distributed in that tissue.

\subsection{Maternal transfer of trace elements during gestation and lactation}

\subsubsection{Placental transfer}

Lanugo appears as a good indicator of the placental transfer of elements to offspring since it reflects the incorporation of elements during the foetal period. It grows during development of the foetus and it is shed around weaning. Results of this study showed that all assayed elements, including $\mathrm{Ni}$ and $\mathrm{Cd}$, were accumulated in grey seals and were transferred to offspring through the placenta. Lanugo seems to be an important site of accumulation for trace elements. A part of the non-essential metals can be already eliminated from early stages of development, as shown for $\mathrm{Hg}$ with $4.6 \mathrm{mg} / \mathrm{kg}$ $\mathrm{dw}$ in the grey seal lanugo.

Levels in lanugo were very much greater than in pup blood. Therefore, lanugo appears more useful than blood to detect the placental transfer of minor trace elements, such as $\mathrm{Ni}$ and $\mathrm{Cd}$. Moreover, pup blood in early lactation was collected at 2-4 days postpartum since it was not possible to collect it immediately after birth for animal care reasons and logistical reasons. This means that pup blood levels measured in early lactation reflect both the placental transfer and the intake from the milk during the first days of lactation. Nevertheless, pup blood provides important indications about the levels of elements circulating in the body, which can affect pup organs and systems in early stages of development.

Calcium, Zn, Fe, and Cu values in pup blood were close to maternal values in early lactation (Fig. 2). For these metals, it is believed that the newborn's needs are met mainly by reserves accumulated during foetal development, especially during the last part of pregnancy (Dorea, 2000). In contrast, a fairly limited transfer of Se through the placenta was observed in grey seals, with pup levels reaching 38\% of the maternal blood value. Despite their very low blood levels, $\mathrm{Pb}, \mathrm{Cr}$, and $\mathrm{V}$ appear efficiently transferred from mother to offspring with, respectively, $100 \%, 144 \%$, and $177 \%$ of the maternal metal value at birth (at 2-4 days postpartum). Transfer of $\mathrm{Hg}$ was lower but nevertheless consistent since pups already showed more than $50 \%$ of the maternal blood value in early lactation. 

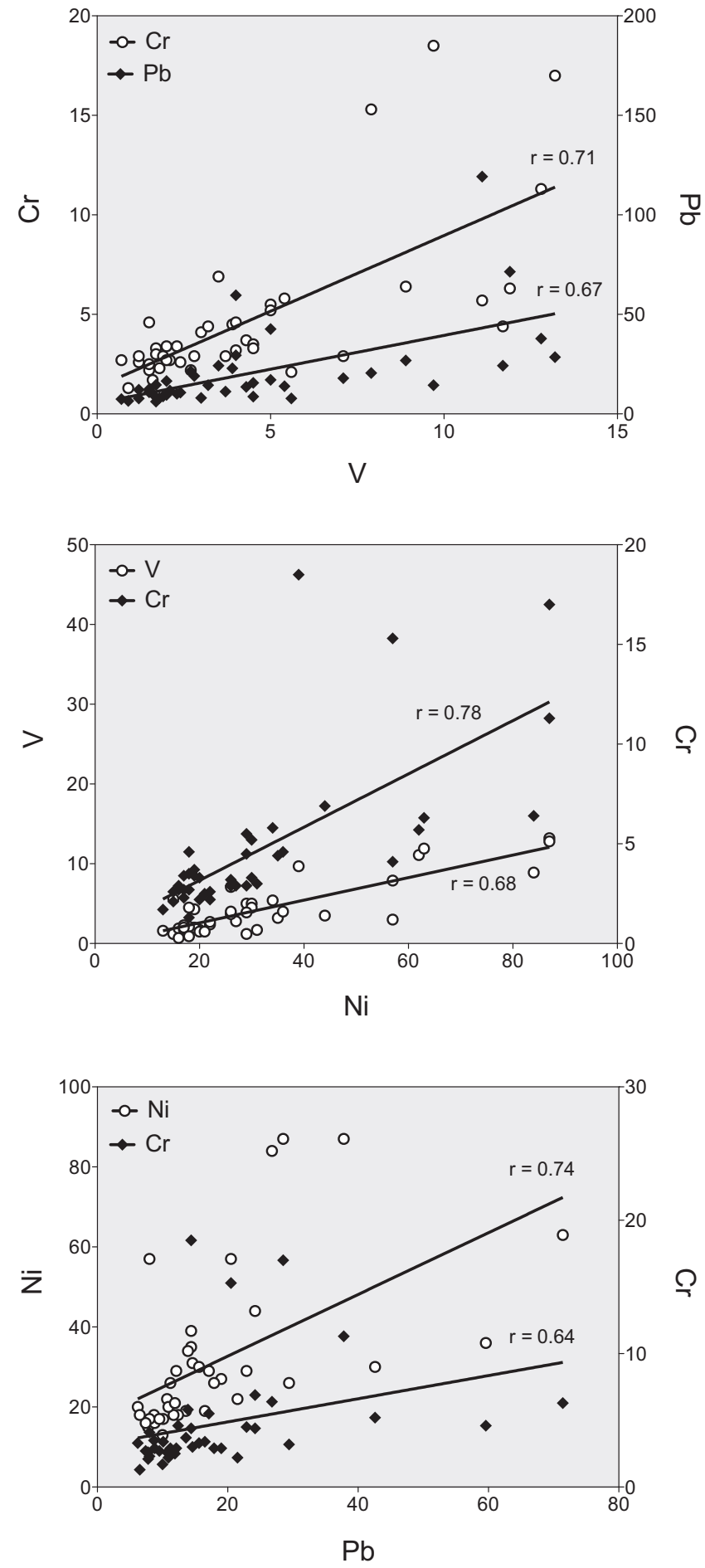

Fig. 4. Relationships between $\mathrm{V}, \mathrm{Cr}, \mathrm{Ni}$, and $\mathrm{Pb}$ in milk of grey seals. Concentrations are expressed in $\mu \mathrm{g} / \mathrm{kg}$ ww (for all correlations $p<0.001$, Spearman's rank correlation coefficient).

\subsubsection{Lactational transfer}

Overall, the mineral content in grey seal milk appears quite high in comparison with the one in terrestrial mammal milk. The high protein content in pinniped milk, being among the highest of any mammal (approximately 10\%, Davis et al., 1995) may contribute to the high mineral content in milk since many metals are usually bound to proteins.

Calcium level in milk was similar to that in other pinniped milk (around $700 \mathrm{mg} / \mathrm{kg} \mathrm{ww}$, Oftedal et al., 1987), higher than in human milk (252 mg/l, Dorea, 1999) and lower than in cow milk ( $1100 \mathrm{mg} / \mathrm{l}$, USDA, 2007). Calcium is a major element for mineralization of bone matrix in offspring and is mostly present in milk complexed with proteins, caseins, in micelles. Surprisingly, pinnipeds have much less calcium in milk than would be predicted based on their high casein content (Jenness, 1979).

Adequate $\mathrm{Fe}$ intake is essential for optimal growth, haematopoiesis and cognitive development in offspring (Kelleher and Lönnerdal, 2005). Grey seals showed similar Fe levels in blood, but very much greater Fe levels in milk $(\sim 20 \mathrm{mg} / \mathrm{kg} \mathrm{ww})$ than other terrestrial mammals ( $<1 \mathrm{mg} / \mathrm{l}$ in humans and ruminants, Anderson, 1992; 4-10 mg/l in rats and dogs, Lönnerdal et al., 1981). As very little information exists about trace elements in milk of marine mammals, levels have been compared with those in terrestrial mammals where any data was available. Three proteins in milk have been reported to bind $\mathrm{Fe}$ in terrestrial species: lactoferrin, transferrin, and casein (Lönnerdal et al., 1981). Grey seal milk is devoid of lactoferrin (Conesa et al., 2008). Casein might be used as iron-binding protein in milk as do some species (i.e., rats and cows), which have no or only low levels of lactoferrin and transferrin in milk (Hegenauer et al., 1979; Loh and Kaldor, 1973). The very large amounts of casein micelles of the pinniped milk (Oftedal, 1993) might contribute to the high level of Fe detected in grey seal milk. Caseins could also bind partially $\mathrm{Zn}$ and $\mathrm{Cu}$ (Lönnerdal et al., 1981). Although Fe levels in maternal blood and milk of grey seals declined throughout the course of lactation, they were not correlated between them. As reported in other mammals (Lönnerdal et al., 1981), Fe transport via mammary gland is a tightly regulated process thus ensuring appropriate Fe transfer to the neonate (Kelleher and Lönnerdal, 2005)

Levels of $\mathrm{Cu}$ and $\mathrm{Zn}$ in grey seal milk were in the same range as values found in terrestrial mammals (Anderson, 1992; Lönnerdal et al., 1981). Copper plays an essential role as a cofactor for enzymes that generate cellular energy, cross-link connective tissue and mobilize cellular iron (Linder et al., 1998). Zinc is a nutrient required for many proteins involved in DNA synthesis, protein synthesis, mitosis and cell division. Adequate Zn supply is particularly important during the periods of rapid neonatal growth and development (Kelleher and Lönnerdal, 2005). Copper and Zn levels increased in pup blood throughout the course of lactation, likely linked to the substantial $\mathrm{Cu}$ and $\mathrm{Zn}$ uptake from the milk. Like $\mathrm{Ca}$ and Fe, mechanisms governing the transfer of $\mathrm{Cu}$ and $\mathrm{Zn}$ from blood to milk are not fully understood, but they do not seem to depend on maternal metal reserves (Dorea, 2000). Little relationship between blood levels and milk levels of these elements was observed in grey seal mothers. The high fat content of pinniped milk might also contribute to high levels of $\mathrm{Fe}, \mathrm{Zn}$, and $\mathrm{Cu}$ detected in grey seal milk. Indeed, it appears that significant portions of $\mathrm{Fe}, \mathrm{Zn}$, and $\mathrm{Cu}$ in human and cow milk are localized in the milk fat fraction (Lönnerdal et al., 1981). However, no relationship with the milk lipid content was observed for these elements in the present study.

Selenium is one of the most important antioxidants in milk. It is essential for health, playing a role in the immune and antioxidant systems and in DNA synthesis and DNA repair (Haug et al., 2007). Milk in grey seals contained a lot of Se, especially in early lactation (around $900 \mu \mathrm{g} / \mathrm{kg}$ ). This value was similar to the level detected in northern elephant seal milk (Habran et al., 2011), and it was much greater than values found in human (13-33 $\mu \mathrm{g} / \mathrm{l}$, Dumont et al., 2006) or cow (11-37 $\mu \mathrm{g} / \mathrm{l}$, Haug et al., 2007). As reported in northern elephant seals (Habran et al., 2011), the high Se uptake from milk increased pup level during suckling, despite decreasing milk level over lactation. It seems that the neonate's needs in Se are met mainly by reserves accumulated during suckling in phocids. Unlike previous elements ( $\mathrm{Ca}, \mathrm{Fe}, \mathrm{Cu}$, and $\mathrm{Zn}$ ), Se level in milk seems to depend on its maternal reserves since it was positively correlated with maternal blood concentrations. 
Grey seal milk contained $\mathrm{Hg}, \mathrm{Pb}, \mathrm{V}, \mathrm{Ni}$, and $\mathrm{Cr}$, and the concentrations were greater than in blood, except for $\mathrm{Hg}$. Interestingly, $\mathrm{Pb}, \mathrm{V}$, $\mathrm{Ni}$, and $\mathrm{Cr}$ showed a significant positive relationship with each other (Fig. 4), suggesting a similar mobilization of these metals through the milk. In contrast with the placental transfer detected in lanugo, it appears that $\mathrm{Cd}$ was not transferred through the mammary gland into the milk. Like in blood, $\mathrm{Pb}, \mathrm{V}, \mathrm{Ni}$, and $\mathrm{Cr}$ in milk appear less tightly regulated through the mammary gland than $\mathrm{Ca}, \mathrm{Cu}$, and $\mathrm{Zn}$, as evidence by their coefficients of variation (Table 4).

\subsection{Variations in tissues throughout lactation and post-weaning} fast

Results showed that the period associated to milk production, fasting, or suckling could affect element levels in tissues of grey seal mothers and pups. Blood and milk concentrations increased or decreased over the course of lactation, depending on the element investigated (Table 5). Interestingly, the same dynamics of $\mathrm{Hg}$ and Se during lactation, including similar transfer ratios at birth and similar variations in concentrations, was found in blood and milk of northern elephant seals (Habran et al., 2011). Each element seems to have its own dynamics during this period, and it is not possible to highlight a general pattern for the mobilization of elements. Nevertheless, these results show that concentrations in tissues can vary rapidly during intense physiological changes. Therefore, these processes could lead to a biased assessment of trace element contamination in marine mammals when different populations or different species are compared. Moreover, important variations in trace element concentrations in the bloodstream could cause damages in diverse organs or systems, especially during growing of offspring.

During lactation, adult females fast and depend entirely on their body fat, mainly from the blubber, to maintain their metabolism and to produce milk. Concentrations of all elements in the maternal blubber increased throughout lactation with the reduction of blubber thickness (Table 5), suggesting a less efficient mobilization of elements from blubber than triglycerides, the dominant lipid type (Henderson et al., 1994). However, elements potentially associated to lipid reserves seem to be not mobilized all in the same way. At the beginning of lactation, elements were distributed homogeneously across the full depth of the blubber layer (no difference between inner and outer layers). During lactation, concentrations of $\mathrm{Ca}, \mathrm{Fe}, \mathrm{Zn}$, and $\mathrm{Cu}$ increased more in the inner blubber and became significantly greater in inner than in outer blubber in late lactation (Table 6). In contrast, concentrations of $\mathrm{V}, \mathrm{Cr}, \mathrm{Ni}$, and $\mathrm{Pb}$ also increased during lactation but remained similar between inner and outer blubber. Fatty acids are mainly mobilized from the inner blubber layer during this period, while the outer part remains more stable (Strandberg et al., 2008). Indeed, for the grey seals of the present study, inner blubber lost $18 \%$ of its lipid content, while outer blubber lost 9\% during lactation (analyses in Vanden Berghe et al., 2012). It seems that $\mathrm{V}, \mathrm{Cr}, \mathrm{Ni}$, and $\mathrm{Pb}$ would be less retained into the inner blubber than $\mathrm{Ca}, \mathrm{Fe}, \mathrm{Zn}$, and $\mathrm{Cu}$. Moreover, significant relationships between $\mathrm{V}, \mathrm{Cr}, \mathrm{Ni}$, and $\mathrm{Pb}$ levels were observed both in blubber and milk suggesting that these 4 elements were mobilized through similar dynamics from the blubber to the milk.

Surprisingly, no change in blubber levels was observed in pups during their post-weaning development, whereas they also fast depending on their reserves accumulated during lactation. Difference in the fat utilization between mothers and pups might affect trace element mobilization in blubber, given approximately $25 \%$ of body fat content is used during post-weaning fast in grey seal pups (Bennett et al., 2007), while approximately 60\% during lactation in grey seal females (Mellish et al., 1999). Interestingly, weaned pups showed very high levels of $\mathrm{Cr}$ and $\mathrm{Ni}$ in their blubber-higher than in maternal blubber-whereas their blood levels were low and $\mathrm{Cr}$ and
Ni milk intake was quite weak. The source of these metals (placental or lactational transfer) remains unclear, since pups are born with a very thin blubber layer, and $\mathrm{Cr}$ and $\mathrm{Ni}$ uptake from milk appears quite low. In any case, an important part of the $\mathrm{Cr}$ and Ni content in grey seals seems to be accumulated during their early stages of development.

\section{Conclusions}

Lanugo analyses in grey seals allowed to highlight the existence of a placental transfer to offspring of all elements investigated in this study. Moreover, results in lanugo showed that a part of the non-essential metals could be already eliminated from the foetal development. A maternal transfer through the milk has also been observed for all elements, except for $\mathrm{Cd}$. Some metals, such as $\mathrm{Hg}$, were transferred to offspring mainly through the placenta during gestation and to a lesser extent during lactation, and inversely for other elements like Se. The placental and mammary barriers against non-essential metal transfer to offspring seemed to be absent or weak in grey seals. There was however an exception for $\mathrm{Cd}$ which was not present into the milk. In addition to the placental transfer, the important daily ingestion of contaminated milk could lead to adverse effects on health of pups from the early stages of development.

Furthermore, this study also showed that element concentrations in tissues (i.e., blood and blubber) could change rapidly over the lactation period. Such physiological processes and their effects must be taken into consideration when interpreting trace element concentrations in the framework of biomonitoring. Moreover, further toxicological studies need to understand the impact that these important fluctuations in concentrations may exert on health of both adults and offspring. To the best of our knowledge, this study represents the first assessment of the levels of trace element contamination in this grey seal population of the North Sea. This population seems lower exposed to $\mathrm{Hg}$, but higher exposed to $\mathrm{Pb}$ than other phocid populations, notably from the North Sea.

\section{Acknowledgements}

The authors thank S. Moss, P. Reimann, C. Morris, W. Paterson, A. Hall, and N. Hanson for their assistance with sample collection on the Isle of May. The authors are also grateful to R. Biondo for his technical assistance. K.D. is a F.R.S.-FNRS Research Associate. S.H. is a F.R.S.-FNRS Research fellow. This study was supported by NSF grant \#0213095 and by FRFC grant \#2.4502.07 (F.R.S.-FNRS). This paper is MARE publication 235.

\section{Appendix A. Supplementary data}

Supplementary data associated with this article can be found, in the online version, at http://dx.doi.org/10.1016/ j.aquatox.2012.08.011.

\section{References}

Agusa, T., Yasugi, S. Iida, A Ikemoto, T. Anan, Y., Kuiken, T., Osterhaus, A.D.M.E. Tanabe, S., Iwata, H., 2011. Accumulation features of trace elements in mass-stranded harbor seals (Phoca vitulina) in the North Sea coast in 2002: the body distribution and association with growth and nutrition status. Marine Pollution Bulletin 62, 963-975.

AMAP, 2005. AMAP Assessment 2002: Heavy Metals in the Arctic. Arctic Monitoring and Assessment Programme (AMAP), Oslo, Norway. xvi + 265 pp. (first published as electronic document in 2004).

Anderson, R.R., 1992. Comparison of trace elements in milk of four species. Journal of Dairy Science 75, 3050-3055.

Andrade, S., Carlini, A.R., Vodopivez, C., Poljak, S., 2007. Heavy metals in molted fur of the southern elephant seal Mirounga leonina. Marine Pollution Bulletin 54, 602-605. 
Baraj, B., Bianchini, A, Niencheski, LF.H, Campos, C.C.R, Martinez, P.E., Robaldo R.B., Muelbert, M.M.C., Colares, E.P., Zarzur, S., 2001. The performance of Zeiss GFAAS-5 instrument on the determination of trace metals in whole blood samples of southern elephant seals (Mirounga leonina) from Antarctica. Fresenius Environment Bulletin 10, 859-862.

Bennett, K.A., Speakman, J.R., Moss, S.E.W., Pomeroy, P., Fedak, M.A., 2007. Effects of mass and body composition on fasting fuel utilisation in grey seal pups (Halichoerus grypus Fabricius): an experimental study using supplementary feeding. Journal of Experimental Biology 210, 3043-3053.

Bossart, G.D., 2006. Marine mammals as sentinel species for oceans and human health. Oceanography 19, 134-137.

Brookens, T.J., Harvey, J.T., O'Hara, T.M., 2007. Trace element concentrations in the Pacific harbor seal (Phoca vitulina richardii) in central and northern California. Science of the Total Environment 372, 676-692.

Bryan, C.E., Christopher, S.J., Balmer, B.C., Wells, R.S., 2007. Establishing baseline levels of trace elements in blood and skin of bottlenose dolphins in Sarasota Bay, Florida: implications for non-invasive monitoring. Science of the Total Environment 388, 325-342.

Bustamante, P., Garrigue, C., Breau, L., Caurant, F., Dabin, W. Greaves, J., Dodemont, R., 2003. Trace elements in two odontocete species (Kogia breviceps and Globicephala macrorhynchus) stranded in New Caledonia (South Pacific). Environmental Pollution 124, 263-271.

Chatt, A., Katz, S., 1988. Hair Analysis, Applications in the Biomedical and Environmental Science. VCH Publishers, New York.

Conesa, C., Sánchez, L., Rota, C., Pérez, M.a.-D., Calvo, M., Farnaud, S., Evans, R.W. 2008. Isolation of lactoferrin from milk of different species: calorimetric and antimicrobial studies. Comparative Biochemistry and Physiology, Part B 150 , 131-139.

Das, K., Debacker, V., Pillet, S., Bouquegneau, J.M., 2003. Heavy metals in marine mammals. In: Vos, J.G., Bossart, G.D., Fournier, M., O'Shea, T.J. (Eds.), Toxicology of Marine Mammals. Taylor \& Francis, London, pp. 135-167.

Das, K., Siebert, U., Gillet, A., Dupont, A., Di-Poï, C., Fonfara, S., Mazzucchelli, G., De Pauw, E., De Pauw-Gillet, M.-C., 2008. Mercury immune toxicity in harbour seals: links to in vitro toxicity. Environmental Health 7, 1-17.

Davis, T.A., Nguyen, H.V., Costa, D.P., Reeds, P.J., 1995. Amino acid composition of pinniped milk. Comparative Biochemistry and Physiology B: Comparative Biochemistry 110, 633-639.

Debier, C., Chalon, C., Le Boeuf, B.J., de Tillesse, T., Larondelle, Y., Thome, J.P., 2006 Mobilization of PCBs from blubber to blood in northern elephant seals (Mirounga angustirostris) during the post-weaning fast. Aquatic Toxicology 80, 149-157.

Debier, C., Pomeroy, P.P., Dupont, C., Joiris, C., Comblin, V., Le Boulenge, E., Larondelle, Y., Thome, J.P., 2003a. Dynamics of PCB transfer from mother to pup during lactation in UK grey seals Halichoerus grypus: differences in PCB profile between compartments of transfer and changes during the lactation period. Marine Ecology Progress Series 247, 249-256.

Debier, C., Pomeroy, P.P., Dupont, C., Joiris, C., Comblin, V., Le Boulenge, E., Larondelle, Y., Thome, J.P., 2003b. Quantitative dynamics of PCB transfer from mother to pup during lactation in UK grey seals Halichoerus grypus. Marine Ecology Progress Series 247, 237-248

Dorea, J.G., 1999. Calcium and phosphorus in human milk. Nutrition Research 19 $709-739$.

Dorea, J.G., 2000. Iron and copper in human milk. Nutrition 16, 209-220.

Dumont, E., Vanhaecke, F., Cornelis, R., 2006. Selenium speciation from food source to metabolites: a critical review. Analytical and Bioanalytical Chemistry 385 1304-1323.

Fedak, M.A., Anderson, S.S., 1982. The energetics of lactation: accurate measurements from a large wild mammal, the grey seal (Halichoerus grypus). Journal of Zoology 198, 473-479.

Godwin, H.A., 2001. The biological chemistry of lead. Current Opinion in Chemica Biology 5, 223-227.

Gray, R., Canfield, P., Rogers, T., 2008. Trace element analysis in the serum and hair of Antarctic leopard seal, Hydrurga leptonyx, and Weddell seal, Leptonychotes weddellii. Science of the Total Environment 399, 202-215.

Griesel, S., Kakuschke, A., Siebert, U., Prange, A., 2008. Trace element concentrations in blood of harbor seals (Phoca vitulina) from the Wadden Sea. Science of the Total Environment 392, 313-323.

Habran, S., Debier, C., Crocker, D.E., Houser, D.S., Das, K., 2011. Blood dynamics of mercury and selenium in northern elephant seals during the lactation period. Environmental Pollution 159, 2523-2529.

Haug, A., Høstmark, A.T., Harstad, O.M., 2007. Bovine milk in human nutrition-a review. Lipids in Health and Disease 6 (25).

Hegenauer, J., Saltman, P., Ludwig, D., Ripley, L., Ley, A., 1979. Iron-supplemented cow milk. Identification and spectral properties of iron bound to casein micelles. Journal of Agricultural and Food Chemistry 27, 1294-1301.
Henderson, R.J., Kalogeropoulos, N., Alexis, M.N., 1994. The lipid composition of selected tissues from a Mediterranean monk seal, Monachus monachus. Lipids 29, 577-582.

Janz, D.M., DeForest, D.K., Brooks, M.L., Chapman, P.M., Gilron, G., Hoff, D., Hopkins, W.A., McIntyre, D.O., Mebane, C.A. Palace, V.P. Skorupa, J.P., Wayland, M., 2010 Selenium toxicity to aquatic organisms. In: Chapman, P.M., Adams, W.J., Delos, C.G., Luoma, S.N., Maher, W.A., Ohlendorf, H.M., Presser, T.S., Shaw, D.P. (Eds.) Ecological Assessment of Selenium in the Aquatic Environment., 1st ed. CRC Press, Pensacola, FL, pp. 141-232.

Jenness, R., 1979. Comparative aspects of milk proteins. Journal of Dairy Research $46,197-210$.

Kakuschke, A., Valentine-Thon, E., Fonfara, S., Griesel, S., Siebert, U., Prange, A., 2006 Metal sensitivity of marine mammals: a case study of a gray seal (Halichoerus grypus). Marine Mammal Science 22, 985-996.

Kelleher, S.L., Lönnerdal, B., 2005. Molecular regulation of milk trace mineral homeostasis. Molecular Aspects of Medicine 26, 328-339.

Kim, Y.Y., Mahan, D.C., 2001. Prolonged feeding of high dietary levels of organic and inorganic selenium to gilts from $25 \mathrm{~kg}$ body weight through one parity. Journal of Animal Science 79, 956-966.

Linder, M.C., Wooten, L., Cerveza, P., Cotton, S., Shulze, R., Lomeli, N., 1998. Copper transport. American Journal of Clinical Nutrition 67, 965S-971S.

Loh, T.T., Kaldor, I., 1973. Iron in milk and milk fractions of lactating rats, rabbits and quokkas. Comparative Biochemistry and Physiology Part B 44, 337-346.

Lönnerdal, B., Keen, C.L., Hurley, L.S., 1981. Iron, copper, zinc and manganese in milk. Annual Review of Nutrition 1, 149-174.

Medvedev, N., Panichev, N., Hyvärinen, H., 1997. Levels of heavy metals in seals of Lake Ladoga and the White Sea. Science of the Total Environment 206 95-105.

Mellish, J.A.E., Iverson, S.J., Bowen, W.D., 1999. Variation in milk production and lactation performance in grey seals and consequences for pup growth and weaning characteristics. Physiological and Biochemical Zoology 72, 677-690.

Oftedal, O.T., 1993. The adaptation of milk secretion to the constraints of fasting in bears, seals, and baleen whales. Journal of Dairy Science 76, 3234-3246.

Oftedal, O.T., Boness, D.J., Tedman, R.A., 1987. The behavior, physiology and anatomy of lactation in the pinnipedia. In: Genoways, H.H. (Ed.), Current Mammalogy. 1 st ed. Springer, New York, pp. 175-245.

OSPAR, 2010. Quality Status Report 2010. OSPAR Comission, London.

Pomeroy, P., Fedak, M., Rothery, P., Anderson, S., 1999. Consequences of maternal size for reproductive expenditure and pupping success of grey seals at North Rona, Scotland. The Journal of Animal Ecology 68, 235-253.

Pomeroy, P.P., Green, N., Hall, J.A., Walton, M., Jones, K., Harwood, J., 1996 Congener-specific exposure of grey seal (Halichoerus grypus) pups to chlorinated biphenyls during lactation. Canadian Journal of Fishery and Aquaculture Sciences 53, 1526-1534.

Reilly, J.J., 1991. Adaptations to prolonged fasting in free-living weaned grey seal pups. American Journal of Physiology 260, 267-272.

Strandberg, U., Kakela, A., Lydersen, C., Kovacs, K.M., Grahl-Nielsen, O., Hyvarinen, H., Kakela, R., 2008. Stratification, composition, and function of marine mammal blubber: The ecology of fatty acids in marine mammals. Physiological and Biochemical Zoology 81, 473-485.

USDA, National Nutrient Database for Standard Reference. http://www.nal.usda.gov/fnic/foodcomp/Data/\%5D. (accessed 03.09.07).

Vanden Berghe, M., Mat, A., Arriola, A., Polain, S., Stekke, V., Thomé, J.-P., Gaspart F., Pomeroy, P., Larondelle, Y., Debier, C., 2010. Relationships between vitamin $\mathrm{A}$ and PCBs in grey seal mothers and pups during lactation. Environmental Pollution 158, 1570-1575.

Vanden Berghe, M., Weijs, L., Habran, S., Das, K., Bugli, C., Rees, J.-F., Pomeroy, P. Covaci, A., Debier, C., 2012. Selective transfer of persistent organic pollutants and their metabolites in grey seals during lactation. Environment International $46,6-15$.

Wagemann, R., Stewart, R.E.A., Lockhart, W.L., Stewart, B.E., Povoledo, M., 1988. Trace metals and methyl mercury: associations and transfer in harp seal (Phoca groenlandica) mothers and their pups. Marine Mammal Science 4, 339-355.

Wenzel, C., Adelung, D., Kruse, H., Wassermann, O., 1993. Trace metal accumulation in hair and skin of the harbour seal, Phoca vitulina. Marine Pollution Bulletin 26, 152-155.

Wolfe, M.F., Schwarzbach, S., Sulaiman, R.A., 1998. Effects of mercury on wildlife: a comprehensive review. Environmental Toxicology and Chemistry 17, 146-160.

Yamamoto, Y., Honda, K., Hidaka, H., Tatsukawa, R., 1987. Tissue distribution of heavy metals in Weddell seals (Leptonychotes weddellii). Marine Pollution Bulletin 18, 164-169.

Yunker, G.B., Hammill, M.O., Gosselin, J.-F., Dion, D.M., Schreer, J.F., 2005. Foetal growth in north-west Atlantic grey seals (Halichoerus grypus). Journal of Zoology 265, 411-419. 